\title{
Internacionalizacija visokega šolstva
}

\author{
UDK: $378: 341.1 / .8$
}

\author{
Alenka Braček \\ Univerza v Ljubljani, Fakulteta za upravo \\ alenka.bracek@fu.uni-lj.si
}

\section{IZVLEČEK}

Kakor sta multikulturnost in multilingvizem postali neizogibni dimenziji sodobne družbe, je internacionalizacija postala neizbežna razsežnost visokega šolstva. Namreč, globalna družba znanja ter težnja po oblikovanju enotnega evropskega visokošolskega prostora, narekujeta poleg drugih modifikacij zahtevo po visoko izobraženi, fleksibilni, ustvarjalni in podjetni delovni sili z močno motivacijo za neprestano učenje, razumevanje različnih kultur in delovanje $v$ mednarodnem okolju. Vse to pa postavlja pred tradicionalne sisteme visokega šolstva številne izzive ter prinaša potrebo po internacionalizaciji kurikula, spremenjenih metodah poučevanja, uvajanju informacijske komunikacijske tehnologije v visokošolsko izobraževanje, mobilnosti študentov in akademskega osebja ter zahtevo po intenzivnem uvajanju novejših oblik internacionalizacije v sfero visokega šolstva. Članek obravnava proces internacionalizacije visokega šolstva in prikazuje rezultate raziskave o stopnji internacionalizacije $v$ članicah javnih visokošolskih institucij v Sloveniji.

Ključne besede: visoko šolstvo, internacionalizacija, globalizacija, oblikovanje skupnega evropskega visokošolskega prostora, spremembe $v$ financiranju visokošolskega izobraževanja

\section{Uvod}

$\checkmark$ zadnjem desetletju postaja internacionalizacija vse bolj pomemben dejavnik $\vee$ delovanju visokošolskih institucij ne samo $v$ Sloveniji, ampak tudi $\vee$ drugih članicah Evropske unije in $v$ državah po svetu, saj pomeni področje aktivnosti, vir potencialnih novosti in finančnih virov, ki vodijo do razvoja novih politik, programov ter praks na institucionalnem, nacionalnem in mednarodnem 
nivoju. Nenazadnje prispeva k temu tudi oblikovanje evropskega trga delovne sile, ki s seboj prinaša nujo po redefiniciji in primerjanju doseženega znanja.

Internacionalizacija visokošolskega izobraževanja je še posebej pomembna z vidika doseganja konkurenčne prednosti Slovenije. Zanemarjanje te razsežnosti ne bi povzročilo le razvojnega zaostanka, pač pa bi $\vee$ sedanjih mednarodnih razmerah hitro vodilo $k$ popolni prevladi tujega znanja. Vključevanje $v$ mednarodne procese na področju izobraževanja je nujno tudi za zagotavljanje kakovosti. Pospeševanje vključevanja v mednarodno sodelovanje in internacionalizacije je naloga države, univerz in drugih samostojnih visokošolskih zavodov (Bela knjiga o vzgoji in izobraževanju, 1995, str. 287).

Slovenski visokošolski prostor se ne more razvijati samo $v$ nacionalnih okvirih, izoliran od drugega sveta. Samo mednarodno odprto visokošolsko izobraževanje bo omogočilo doseganje ciljev, ki si jih je Slovenija zadala s podpisom Bolonjske deklaracije in Lizbonske strategije ter se tako prilagodila zahtevam globalne ekonomije. Poleg uspešnega vključevanja v evropske integracijske procese pa je enako pomemben cilj utrjevanja narodne identitete $z$ uveljavljanjem odličnosti slovenske znanosti ter ohranjanje bogastva naravne in kulturne dediščine. To pa pomeni, da se morajo visokošolske institucije $v$ Sloveniji intenzivneje posvetiti obravnavanju vplivov globalizacije, integracijskih procesov, liberalizacije mednarodne trgovine in trgov, ki so $v$ zadnjih treh desetletjih dramatično zaznamovali področje visokega šolstva, ter poiskati najboljše možnosti za prilagoditev tem novim pogojem tako na institucionalnem kot na nacionalnem nivoju. Neosveščenost o prednostih in koristih, ki jih prinaša internacionalizacija visokega šolstva, ter pasivna vloga glede uvajanja različnih oblik internacionalizacije $v$ sfero visokega šolstva lahko Slovenijo privede do stanja izoliranosti in nekonkurenčnosti.

\section{Opredelitev pojma internacionalizacije visokega šolstva}

Internacionalizacija $v$ najširšem pomenu besede obsega vse oblike mednarodnega sodelovanja. Z ekonomskega vidika se internacionalizacija nanaša na širjenje ekonomske dejavnosti v več držav oziroma na vključevanje podjetij v mednarodno menjavo in mednarodno proizvodnjo, tako z vidika menjave blaga 
in storitev oziroma tekočega kapitalskega dela plačilne bilance, kot tudi določenih oblik mednarodnega ekonomskega sodelovanja, ki v slednjih sploh niso zajete (Svetličič, 1996, str. 52). Z vidika visokošolskega izobraževanja je internacionalizacija pogosto opredeljena kot koncept in proces integriranja mednarodnih povezav $\vee$ učenje, raziskovanje in storitvene funkcije visokošolskih institucij. Internacionalizacija visokega šolstva pomeni različne aktivnosti za različne akterje na področju visokega šolstva, rezultat tega pa je velika raznolikost interpretacij, ki jih pripisujejo temu pojmu. Za nekatere internacionalizacija pomeni mednarodne aktivnosti, kot so: mobilnost študentov in akademskega osebja, mednarodne povezave, partnerstva, projekti in skupni študijski programi. Za druge pa je to transnacionalno izobraževanje, ki v širšem pomenu obsega: skupne programe izobraževanja dveh ali več institucij $\vee$ domači in tuji državi; podružnice institucij, ki delujejo v drugi državi; institucije, ki nudijo izobraževanje na daljavo; mednarodne institucije ter virtualne univerze (Knight, 2006, str. 11).

Čeravno se koncept internacionalizacije uporablja že stoletja na različnih področjih delovanja posamezne države, pa se je pojem $v$ visokem šolstvu prvič pojavil šele $\vee$ začetku osemdesetih let prejšnjega stoletja. Pred tem sta se najpogosteje uporabljala pojma mednarodno izobraževanje in mednarodno sodelovanje. Od začetka osemdesetih let 20. stoletja pa vse do začetka novega tisočletja se številni strokovnjaki s tega področja nikakor niso mogli sporazumeti glede enotne definicije internacionalizacije visokega šolstva. Končni predlog opredelitve pojma je leta 2003 podala Jane Knight iz Univerze v Torontu. Definicija se je vse do danes uveljavila $v$ večini držav na območju Amerike, Avstralije in Evrope. Opredelitev, ki je zelo splošna, tako da se lahko prilagodi različnim državam, kulturam in izobraževalnim sistemom in ne specificira konkretnih razlogov, prednosti, rezultatov in akterjev, saj le-ti variirajo glede na posamezno državo, je naslednja: internacionalizacija visokega šolstva na nacionalnem, sektorskem in institucionalnem nivoju je proces integracije mednarodne, medkulturne in globalne razsežnosti $v$ cilje, delovanje (poučevanje, učenje, raziskovanje ter storitve) visokošolskih institucij (Knight, 2004, str. 6). 


\section{Izhodišča za internacionalizacijo visokega šolstva}

Če želimo obravnavati proces internacionalizacije, nikakor ne smemo prezreti okolja, v katerem visoko šolstvo deluje. $\vee$ zadnjem desetletju so se visokošolske institucije povsod po svetu soočile z mnogimi spremembami in odločilnimi premiki, $\mathrm{ki}$ so narekovali temeljite spremembe $\vee$ njihovem delovanju. Med te spremembe lahko na prvo mesto uvrstimo proces globalizacije, ki je najmočnejši razlog za spreminjajoče se okolje visokega šolstva, tej spremembi pa sledijo še težnja po uvedbi skupnega evropskega visokošolskega prostora (Bolonjski proces), Lizbonska strategija in spremembe v financiranju visokošolskih institucij.

\subsection{Globalizacija}

Pospešena globalizacija na področju svetovne trgovine je s proizvodi in storitvami postavila dodatne izzive tudi visokemu šolstvu, saj so se pojavile težnje po premiku regulacije izobraževanja od nacionalne ravni k nadnacionalnim telesom odločanja, predvsem $k$ tistim $v$ okviru svobodne trgovine. Naraščajoča privatizacija visokega šolstva posledično povzroča, da je ponudba izobrazbe (predvsem novih, razvojno naravnanih programov) vse bolj vezana na potrebe trga. K temu je precej pripomogel tudi Sporazum o trgovini s storitvami (GATS), ki je uvedel drugačno obravnavo storitev $v$ mednarodni menjavi, vplivali pa so tudi deregulacijski ukrepi držav in internacionalizacija na področju storitvenih dejavnosti (Stare, 2002, str. 5). $\vee$ tabeli 1 je prikazanih pet elementov globalizacije, ki vplivajo na delovanje in na mednarodno dimenzijo visokega šolstva.

Iz tabele 1 je razvidno, da spremembe, ki jih prinaša globalizacija, vplivajo na vse vidike visokega šolstva, s procesi poučevanja in kurikuli, na mobilnost študentov in akademskega osebja, mednarodne razvojne projekte, različne programe tujih jezikov, razvoj zaposlenih in transnacionalno izobraževanje. 
Tabela 1: Vplivi globalizacije na internacionalizacijo visokega šolstva

\begin{tabular}{|c|c|c|}
\hline $\begin{array}{c}\text { ELEMENTI } \\
\text { GLOBALIZACIJE }\end{array}$ & VPLIV NA VISOKO ŠOLSTVO & $\begin{array}{c}\text { VPLIV NA } \\
\text { INTERNACIONALIZACIJO } \\
\text { VISOKEGA ŠOLSTVA }\end{array}$ \\
\hline $\begin{array}{l}\text { NA ZNANJU } \\
\text { TEMELJEčA } \\
\text { DRUŽBA } \\
\text { Povečana pomem- } \\
\text { bnost, ki se nanaša na } \\
\text { produkcijo znanja. }\end{array}$ & $\begin{array}{l}\text { - Poudarek na vseživljenjskem } \\
\text { učenju in nenehnem strokov- } \\
\text { nem izpopolnjevanju. } \\
\text { - Zahteva po razvoju novih veščin } \\
\text { in spretnosti, ki se izkazuje v } \\
\text { novih izobraževalnih programih } \\
\text { in kvalifikacijah. } \\
\text { - Delovanje univerz, ki je doslej } \\
\text { temeljilo na raziskovanju in zna- } \\
\text { nju, se spreminja v komerciali- } \\
\text { zacijo. }\end{array}$ & $\begin{array}{l}\text { Novi javni in privatni ponudniki } \\
\text { izobraževalnih storitev. } \\
\text { Transnacionalno izobraževanje. } \\
\text { Izobraževalni programi se odzivajo } \\
\text { na potrebe trga delovne sile. } \\
\text { Povečana stopnja mobilnosti } \\
\text { študentov, akademskega osebja, } \\
\text { programov, ki vodijo do dvoj- } \\
\text { ne/skupne diplome. }\end{array}$ \\
\hline $\begin{array}{l}\text { INFORMACIJSKA IN } \\
\text { KOMUNIKACIJSKA } \\
\text { TEHNOLOGIJA }\end{array}$ & $\begin{array}{c}\text { Povečane možnosti posredovanja } \\
\text { izobraževalnih storitev (on-line, } \\
\text { satellite based, ...) }\end{array}$ & $\begin{array}{l}\text { Inovativnejši načini posredovanja } \\
\text { izobraževalnih storitev (e-učenje, } \\
\text { podružnice, kampusi, ...) }\end{array}$ \\
\hline $\begin{array}{l}\text { TRŽNA EKONOMIJA } \\
\text { Vpliv tržne } \\
\text { ekonomije. }\end{array}$ & $\begin{array}{l}\text { Visoko šolstvo in izobraževalni } \\
\text { programi usposabljanja v vse večji } \\
\text { meri prevzemajo komercialno } \\
\text { naravo. }\end{array}$ & $\begin{array}{l}\text { Preoblikovanje kurikula in študijskih } \\
\text { gradiv. }\end{array}$ \\
\hline $\begin{array}{l}\text { LIBERALIZACIJA } \\
\text { TRGOVINE }\end{array}$ & $\begin{array}{c}\text { Povečalo se je transnacionalno } \\
\text { izobraževanje. }\end{array}$ & $\begin{array}{l}\text { Večji poudarek je namenjen } \\
\text { transnacionalnemu izobraževanju. }\end{array}$ \\
\hline $\begin{array}{l}\text { NACIONALNI } \\
\text { ORGANI } \\
\text { Ustanavljanje novih } \\
\text { nacionalnih organov, } \\
\text { struktur, sistemov } \\
\text { namenjenih za med- } \\
\text { narodno sodelovanje. }\end{array}$ & $\begin{array}{l}\text { Vloga nacionalnih organov ter } \\
\text { agencij, pristojnih za visoko šols- } \\
\text { tvo, se spreminja. }\end{array}$ & $\begin{array}{l}\text { V ospredje prihajajo nove aktivnosti: } \\
\text { zagotavljanje kakovosti, akreditacija, } \\
\text { prenos ECTS, priznavanje kvalifikacij } \\
\text { in mobilnost študentov. }\end{array}$ \\
\hline
\end{tabular}

Vir: (Knight, 2005, str. 3-4) 


\section{Alenka Braček \\ Internacionalizacija visokega šolstva}

\subsection{Oblikovanje skupnega evropskega visokošolskega prostora (Bolonjski proces)}

Vzpostavitev povezovalnega in odprtega evropskega prostora izobraževanja in usposabljanja je v času globalizacije postalo ključnega pomena za prihodnost Evrope ter njenih državljanov. Le na podlagi oblikovanja skupnega evropskega visokošolskega prostora bo Evropa lahko dovolj konkurenčna drugemu svetu in bo okrepila svoje intelektualne, kulturne, socialne, znanstvene in tehnološke razsežnosti. Oblikovanje skupnega evropskega visokošolskega prostora oz. t. i. Bolonjski proces lahko označimo kot skupno prizadevanje evropskih držav (bolj natančno: njihovih resorjev za izobraževanje), nekaterih vladnih in nevladnih mednarodnih organizacij za izobraževanje, univerz in študentskih organizacij za koordinirano sodelovanje in poenotenje pogledov pri reševanju izzivov in odprtih vprašanj o ključnih konceptih, strategijah in razvojnih politikah visokega šolstva v razmerah, ki jih zaznamujejo evropske integracije, t. i. tranzicija $\vee$ srednji in vzhodni Evropi ter globalizacija $\vee$ svetovnem merilu (Zgaga, 2004, str. 11). V genezi oblikovanja skupnega evropskega visokošolskega sistema je nastalo več dokumentov, ki jih lahko razdelimo $v$ dva sklopa. K prvemu sklopu spadajo dokumenti, ki so bili podpisani pred uradnim pričetkom Bolonjskega procesa. To so Magna Charta Universitatum', Erfurtska deklaracija, Lizbonska konvencija ${ }^{\mathbf{2}}$ in Sorbonska deklaracija ${ }^{\mathbf{3}}$. Lahko bi rekli, da so to preambule Bolonjskega procesa. $\vee$ drugem delu so bile sprejete Bolonjska deklaracija ${ }^{4}$, študentska deklaracija iz Göteborga ${ }^{\mathbf{5}}$, Lizbonska strategija ${ }^{\mathbf{6}}$, Praški komunike ${ }^{7}$, Graška deklaracija ${ }^{\boldsymbol{8}}$ in Berlinski komunike ${ }^{\boldsymbol{9}}$. V vseh dokumentih je

\footnotetext{
1 Dokument dosegljiv na: http://www.bologna-bergen2005.no/Docs/00-

Main_doc/880918_Magna_Charta_Universitatum.pdf

2 Dokument dosegljiv na:

http://www.dfes.gov.uk/bologna/uploads/documents/Lisbon_Convention.htm

3 Dokument dosegljiv na:

http://www.dfes.gov.uk/bologna/uploads/documents/SORBONNE_DECLARATION1.pdf

4 Dokument dosegljiv na:

http://www.dfes.gov.uk/bologna/uploads/documents/BOLOGNA_DECLARATION1.pdf

5 Dokument dosegljiv na: http://www.see-educoop.net/education_in/pdf/student-goteborgdeclaration-oth-sln-t02.htm

6 Dokument dosegljiv na:

http://consilium.europa.eu/ueDocs/cms_Data/docs/pressData/en/ec/00100-r1.en0.htm

7 Dokument dosegljiv na:

http://www.dfes.gov.uk/bologna/uploads/documents/PRAGUE_COMMUNIQUE2.pdf

8 Dokument dosegljiv na:

http://www.eua.be/eua/jsp/en/upload/COM_PUB_Graz_publication_final.1069326105539.pdf

9 Dokument dosegljiv na:

http://www.dfes.gov.uk/bologna/uploads/documents/Berlin_Communique1.pdf
} 


\section{Alenka Braček \\ Internacionalizacija visokega šolstva}

internacionalizacija visokega šolstva označena kot pomemben dejavnik predvsem z vidika prispevanja intelektualnega kapitala k mednarodni skupnosti, akademskemu napredku in medsebojnem razumevanju.

\subsection{Lizbonska strategija}

Hitra gospodarska rast $v$ ZDA z bliskovitim informacijsko - mikroelektronskim vzponom ter japonsko in vzhodnoazijsko naraščajočo delovno tehnološko superiornostjo je še okrepila prepričanje, da mora skupni evropski prostor postati na znanju temelječa, najbolj konkurenčna regija sveta. Države članice so se skupaj odločile, da strnejo svoje ustvarjalne in inovativne potenciale - ne v smislu tekmovanja in dokazovanja odličnosti posameznih nacionalnih sistemov izobraževanja in usposabljanja - temveč v iskanju trdnega zavezništva, usmerjenega $v$ iskanje optimalnih sinergij med nacionalnimi in evropskimi rešitvami zlasti $\vee$ izobraževalnem in raziskovanem prostoru (Lorber, 2004, str. 1). Cilj Lizbonske strategije je, da Evropska unija do leta 2010 postane najbolj konkurenčno in dinamično, na znanju zasnovano gospodarstvo na svetu, sposobno trajnostne gospodarske rasti $z$ več in boljšimi delovnimi mesti ter večjo socialno kohezijo ${ }^{10}$.

S strategijo je bil dosežen konsenz, da bo za uresničitev modela Evrope s konkurenčnim gospodarstvom, trajnostnim razvojem, visoko socialno kohezijo in ohranjenim okoljem odločilno prispeval človeški potencial oz. bodo to posamezniki, sposobni tvoriti novo, inovativno znanje. Ustvarjalni posamezniki, sposobni polno uresničiti svoje potenciale, se oblikujejo skozi formalno izobraževanje in usposabljanje kot tudi skozi proces vseživljenjskega učenja, ko si pridobivajo znanje, spretnosti in kompetence ne le za delo, temveč tudi za življenje, za trajnostni osebni razvoj in aktivno državljanstvo. To je poslanstvo in vloga izobraževanja in usposabljanja v Lizbonski strategiji (Lorber, 2004, str. 1).

Lizbonska strategija je zato postavila Svetu za izobraževanje (Council of Education) nalogo, da se odzove in zavzame stališče o konkretnih prihodnjih ciljih izobraževalnih sistemov, pri čemer naj se osredotoči na skupne zadeve in prioritete, upoštevajoč nacionalne razlike (Lizbonska strategija, 2000, 27 čl.).

10 Dokument dosegljiv na:

http://consilium.europa.eu/ueDocs/cms_Data/docs/pressData/en/ec/00100-r1.en0.htm 


\section{Alenka Braček \\ Internacionalizacija visokega šolstva}

Tako je februarja 2002 nastal dokument Detailed work programme on the follow-up of the objectives of educational and training systems in Europe (t. i. Objectives Report ${ }^{11}$ ), ki je od takrat v središču vseh diskusij o izobraževalnih politikah. Objectives Report poudarja, da sta izobraževanje in usposabljanje »ključno prednostno področje $\vee$ Lizbonski strategiji», $\vee$ osrednjem delu pa predstavi delovni program za uresničevanje 13 ciljev. Prvih pet ciljev je usmerjenih k izboljševanju kakovosti in učinkovitosti sistemov izobraževanja in usposabljanja $\vee$ Evropski uniji, naslednji trije poudarjajo širitev in olajševanje dostopa do izobraževanja in usposabljanja, zadnjih pet pa njihovo odpiranje navzven. Pri tem dokument zaključuje, da je $\vee$ evropski družbi znanja treba državljanom omogočiti, da se bodo lahko učili in delali skupaj v vsej Evropi ter da bodo povsod lahko v polni meri uporabljali svoje znanje. Čeravno so se ovire pri mobilnosti in priznavanju kvalifikacij že začele odpravljati, tako s pomočjo instrumentov Evropske unije (kot so ECTS ali univerzitetna partnerstva v okviru programa Socrates) kot $s$ pomočjo Bolonjskega procesa, pa na mnogih področjih ostaja še veliko dela. Zato je treba visokošolske ustanove in druge izobraževalne oblasti spodbujati k razvijanju bolj kompatibilnih sistemov kvalifikacij po vsej Evropi in k skupnemu razumevanju tega, kaj je minimalna raven zahtevane kakovosti za akreditacijo. Okrepiti je treba politike na področju preglednosti in priznavanja kvalifikacij. Podpirati je treba razvoj skupnih diplom in kvalifikacij ter akreditacijskih sistemov, če naj bodo evropske izobraževalne ustanove $v$ svetu priznane kot centri odličnosti (Commission of the European Communities, 2002, str. 42).

\subsection{Spremembe v financiranju visokošolskega izobraževanja}

Podlaga za spremembe $\vee$ financiranju visokošolskega izobraževanja $\vee$ Evropi je Erfurtska deklaracija o avtonomiji univerze s podnaslovom Za odgovorno univerzo enaindvajsetega stoletja, ki je bila sprejeta marca 1999. Podpisalo jo je štirinajst predstavnikov evropskega akademskega sveta (predstavniki univerz, predsednik rektorske konference in podobno) ter slovenski, nemški in estonski pristojni ministri. Financiranje visokega šolstva je zajeto $v$ tretjem delu deklaracije, $v$ katerem odločitev o obsegu in namenih državnega financiranja

11 Dokument dosegljiv na:

http://eric.ed.gov/ERICWebPortal/contentdelivery/servlet/ERICServlet?accno=ED479339 


\section{Alenka Braček
Internacionalizacija visokega šolstva}

univerze prepušča posameznim državam, poziva pa jih k stabilnemu financiranju brez večjih nihanj iz leta $v$ leto. To naj bi omogočalo razumno stopnjo vnaprejšnjega načrtovanja. Poleg tega poglavitno smernico $v$ zvezi s financiranjem visokega šolstva predstavlja usmeritev, da univerze ne smejo biti odvisne samo od državnega vira sredstev, ampak bi si morale poiskati širšo paleto možnih finančnih virov, na primer tudi gospodarstvo. Gospodarstvo bi tako v zameno za svoja sredstva lahko pričakovalo praktično uporabno znanje, ki bi prispevalo k večji učinkovitosti. ${ }^{12}$ Kot navaja Gibbs $(2001$, str. 87) je ta usmeritev povzročila dojemanje izobraževanja kot proizvoda. Tak pogled daje večji pomen končnim rezultatom kot njihovemu notranjemu pomenu, kar vodi do tako imenovanega outcome-driven izobraževanja. Pri tem velja, da je izobraževalni proces postranskega pomena in "končni proizvod" ni izobražena oseba v klasičnem pomenu, ampak oseba, ki je sposobna svoja pridobljena znanja uporabiti predvsem pri izpolnjevanju svojih ekonomskih želja. Tudi na srečanju partnerjev Svetovne konference o visokem šolstvu (junij 2003), ki je temeljilo na poglavitnih načelih Svetovne deklaracije o visokem šolstvu v 21. stoletju, so bili opredeljeni štirje najpomembnejši elementi razvojnih premikov $v$ visokem šolstvu, ki se navezujejo na prejšnjo trditev: 1. vse večji pomen na znanju temelječi družbi in gospodarstvu; 2. oblikovanje novih trgovinskih sporazumov, ki vključujejo trgovanje z izobraževalnimi storitvami; 3. inovacije, povezane z informacijsko in komunikacijsko tehnologijo ter 4. poudarjena vloga trgov in tržnega gospodarstva (UNESCO, 2004).

Spremembe $v$ financiranju visokošolskega izobraževanja pomenijo eno od ključnih izhodišč za internacionalizacijo visokega šolstva. Povečano število študentov ter s tem povečano povpraševanje po izobraževalnih storitvah so veliko finančno breme za posamezno državo. Odločitev o novem, integralnem financiranju visokega šolstva daje univerzam večjo finančno avtonomijo, na drugi strani pa terja njihovo večjo odgovornost. Kot rezultat tega se $v$ zadnjem obdobju pojavljajo diverzifikacija, privatizacija in komercializacija visokega šolstva. Posledično se tako od javnih kot od privatnih visokošolskih institucij zahteva, da iščejo druge alternativne vire prihodkov. Finančni viri so ponavadi različne fundacije in privatne korporacije, prihodki od komercializacije raziskav ter prihodki od šolnin domačih in tujih študentov ter šolnin študentov, ki so vpisani na študijski program, ki ga visokošolska institucija izvaja v tujini. ${ }^{\mathbf{1 3}} \mathrm{V}$ prihodnjem

12 Povzeto po (Zgaga, 2005, str. 4-7)

13 Povzeto po (Knight, 2005, str. 8-9) 
obdobju lahko pričakujemo, da se bo število študijskih programov, ki jih bodo visokošolske institucije "prenesle" in izvajale v tujini, zaradi potenciala finančnih sredstev, ki ga ta dejavnost prinaša, še povečalo (Larsen et al. 2002, str. 9). Trg visokošolskih storitev bo zato $v$ prihodnosti še bolj tekmovalen (Knight, 2005, str. 9).

\section{Raziskava o internacionalizaciji visokega šolstva v Sloveniji}

$\checkmark$ nadaljevanju so predstavljeni izsledki kvantitativne raziskave o stopnji internacionalizacije $\vee$ vseh štirih univerzah $\vee$ Sloveniji (Univerza $\vee$ Ljubljani, Univerza v Mariboru, Univerza na Primorskem, Univerza v Novi Gorici), ki je bila opravljena $v$ letu 2007. Raziskava je bila izvedena na podlagi izpolnjenih vprašalnikov o internacionalizaciji, ki so bili $\vee$ elektronski obliki posredovani tajnikom ter odgovornim za mednarodno sodelovanje $v$ vseh javnih fakultetah $v$ Sloveniji. Za sodelovanje pri raziskavi se je izmed pozvanih fakultet (50) odzvalo (28) fakultet, kar je 56\% delež vseh javnih fakultet $\vee$ Sloveniji. $\vee$ raziskavo namenoma nista bili zajeti dve fakulteti, ki sta $v$ okviru Univerze $v$ Mariboru šele $v$ fazi ustanovitve. Raziskava o internacionalizaciji visokega šolstva $\vee$ Sloveniji je poglobljena tudi z ugotavljanjem podobnosti in razlik med odgovori, ki so jih podale fakultete s področja družboslovnih in humanističnih ved (skupina A) ter naravoslovnih, inženirskih in tehnoloških ved, medicinskih ter kmetijskih ved (skupina B). Pri razvrščanju fakultet $v$ skupino $A$ in $B$ se je upoštevalo načelo sorodnosti znanstvenih disciplin. Pri klasifikaciji razvrščanja posameznih fakultet pa je bil upoštevan Frascatski priročnik ${ }^{\mathbf{1 4}}$ (področja znanosti in tehnike).

$\checkmark$ drugem delu raziskave je prikazana primerjava posameznih vprašanj oz. odgovorov z vprašanji oz. odgovori (274) evropskih fakultet, ki so sodelovale v raziskavi Internationalization of Higher Education ${ }^{\mathbf{1 5}}$, ki jo je med visokošolskimi institucijami v svetu leta 2006 izvedla International Association of Universities (IUA). Pri tem naj bi se ugotovile podobnosti in razlike pri izvajanju internacionalizacije na fakultetah $\vee$ Sloveniji in Evropi. Ta del raziskave je še posebej

14 Javna agencija za raziskovalno dejavnost RS (ARRS): Področja znanosti in tehnike po Frascatskem priročniku. Dostopno na: http://www.arrs.gov.si/sl/gradivo/sifranti/inc/siffrascati.pdf

15 Knight, J. (2006): 2005 IAU Global Survey Report: Internationalization of Higher Education: New Directions, New Challenges. Pariz. International Association of Universities (IAU). 
pomemben zato, ker $v$ raziskavo Internationalization of Higher Education slovenske fakultete niso bile vključene. $\vee$ nadaljevanju so predstavljeni izsledki raziskave glede na naslednja področja:

- pomembnost in razlogi za internacionalizacijo visokega šolstva;

- institucionalna strategija za internacionalizacijo visokega šolstva;

- stopnja vključenosti in oblike internacionalizacije visokega šolstva;

- koristi in nevarnosti internacionalizacije visokega šolstva;

- priložnosti in ovire;

- predlogi za spremembe.

\subsection{Pomembnost in razlogi za internacionalizacijo visokega šolstva}

Glede pomena, ki ga pripisujejo internacionalizaciji visokega šolstva, se tako fakultete $\vee$ Sloveniji kot fakultete $\vee$ Evropi zavedajo visokega pomena internacionalizacije za sfero visokega šolstva. Ob tem je zanimiv podatek, da internacionalizaciji visokega šolstva pripisujejo večji pomen matične univerze $(86 \%)$ in nacionalni organi visokega šolstva v Sloveniji (61\%) kot pa ga internacionalizaciji pripisujejo matične univerze $(53 \%)$ in nacionalni organi $\vee$ Evropi (45\%).

Poglavitni razlogi, ki vodijo $\mathrm{k}$ dejavnostim internacionalizacije na fakultetah $\checkmark$ Sloveniji so: izboljšanje kakovosti visokošolskega izobraževanja; krepitev raziskovalnih in pedagoških zmožnosti; prispevek k povečanju znanja in sposobnosti za delovanje diplomantov $v$ mednarodnem okolju ter povečanje njihovega medkulturnega razumevanja. Poglavitni razlogi za uvajanje internacionalizacije na fakultetah $\vee$ Evropi pa so: mednarodni sloves visokošolskih institucij ter povečevanje njihovega ugleda. Sledita enaka razloga, kot so ju navedle tudi slovenske fakultete: prispevek k povečanju znanja in sposobnosti za delovanje diplomantov $\vee$ mednarodnem okolju ter krepitev raziskovalnih in pedagoških zmožnosti. Zaključimo lahko, da je poglavitni razlog za izvajanje procesa internacionalizacije na fakultetah $v$ Evropi $v$ mednarodnem slovesu visokošolskih institucij in $\vee$ povečevanju ugleda, ne pa kakovost visokošolskega izobraževanja, kar pomeni poglavitni razlog za slovenske fakultete, ki so sodelovale $v$ raziskavi. 


\subsection{Institucionalna strategija za internacionalizacijo visokega šolstva}

$\checkmark$ zvezi z institucionalno strategijo za internacionalizacijo visokega šolstva je bilo ugotovljeno, da ima le 10 fakultet $\vee$ Sloveniji, to je $36 \%$, izdelan program dela za področje internacionalizacije in da celo 18 fakultet oz. 64\% fakultet, ki so sodelovale $v$ raziskavi, sploh nima izdelanega programa dela za internacionalizacijo. Glede na znanstveno področje fakultet, ki imajo izdelano strategijo oz. program dela za internacionalizacijo visokega šolstva, je zanimivo, da imajo izdelan program dela pretežno fakultete s področja družboslovnih in humanističnih ved. Na fakultetah s področja naravoslovnih, inženirskih in tehnoloških ved, medicinskih ter kmetijskih ved se aktivnosti s področja internacionalizacije visokega šolstva izvajajo nenačrtovano, kar je bilo dokazano tudi kot statistično značilno. Glede na to, da ima večina fakultet (84\%) v Evropi izdelan strateški načrt oz. program dela za področje internacionalizacije visokega šolstva, so podatki za Slovenijo v tem pogledu, zelo zaskrbljujoči. Še več, ta podatek je še posebno sporen, ker kaže na nezavedanje pomembnosti celotnega procesa internacionalizacije na fakultetah $\vee$ Sloveniji ter brezbrižnost do utemeljevanja finančnih investicij, vloženih $\vee$ aktivnosti internacionalizacije. Na podlagi tega lahko sklepamo, da se $\vee$ primerjavi z Evropo, $v$ Sloveniji proces internacionalizacije visokega šolstva izvaja dokaj nepopolno in nedosledno, brez jasno izraženih strategij, ciljev in rezultatov. Kakor pa menita Green in Olson (v: Tsuruta, 2005, str. 20), je nadvse pomembno, da vsaka visokošolska institucija pripravi vizijo svojega delovanja, kjer je vključena tudi internacionalizacija, ter soglasno sprejme prioritete tega delovanja.

\subsection{Stopnja vključenosti in oblike internacionalizacije visokega šolstva}

$\checkmark$ procese internacionalizacije so na fakultetah $\vee$ Sloveniji najpogosteje vključeni: pedagoški delavci (93\%); vodstvo fakultete (82\%) in študenti (71\%). Nizka vključenost mednarodnih pisarn $(43 \%) \vee$ procese internacionalizacije je predvsem odraz stanja, ker večina fakultet $v$ Sloveniji sploh nima vzpostavljene mednarodne pisarne oz. sistemiziranega delovnega mesta za to področje. Med raziskavo je bilo posredno ugotovljeno tudi, da se $s$ to dejavnostjo ukvarjajo predvsem mladi asistenti oz. drugi strokovni delavci, ki pa se poleg rednih pedagoških obveznosti oz. drugih delovnih obveznosti tej dejavnosti ne morejo 
posvetiti v takšni meri, kot bi se lahko delavci oz. organizacijska enota, ki bi se ukvarjala samo $s$ to dejavnostjo. Prav tako je bila na tem mestu izpostavljena tudi finančna ovira, saj delo, ki ga ti delavci opravljajo izven svojih delovnih obveznosti, ni dodatno finančno ovrednoteno. Na tem mestu se nam zastavlja vprašanje glede kakovosti, učinkovitosti in uspešnosti opravljanja te dejavnosti na javnih fakultetah $\vee$ Sloveniji. Glede na primerjavo $s$ fakultetami $\vee$ Evropi je stanje zelo sporno, saj ima celo $70 \%$ fakultet v Evropi vzpostavljeno organizacijsko enoto, ki skrbi samo za področje internacionalizacije visokega šolstva.

\section{Slika 1: Relativna razmerja v zvezi s strateškim načrtom internacionalizacije}

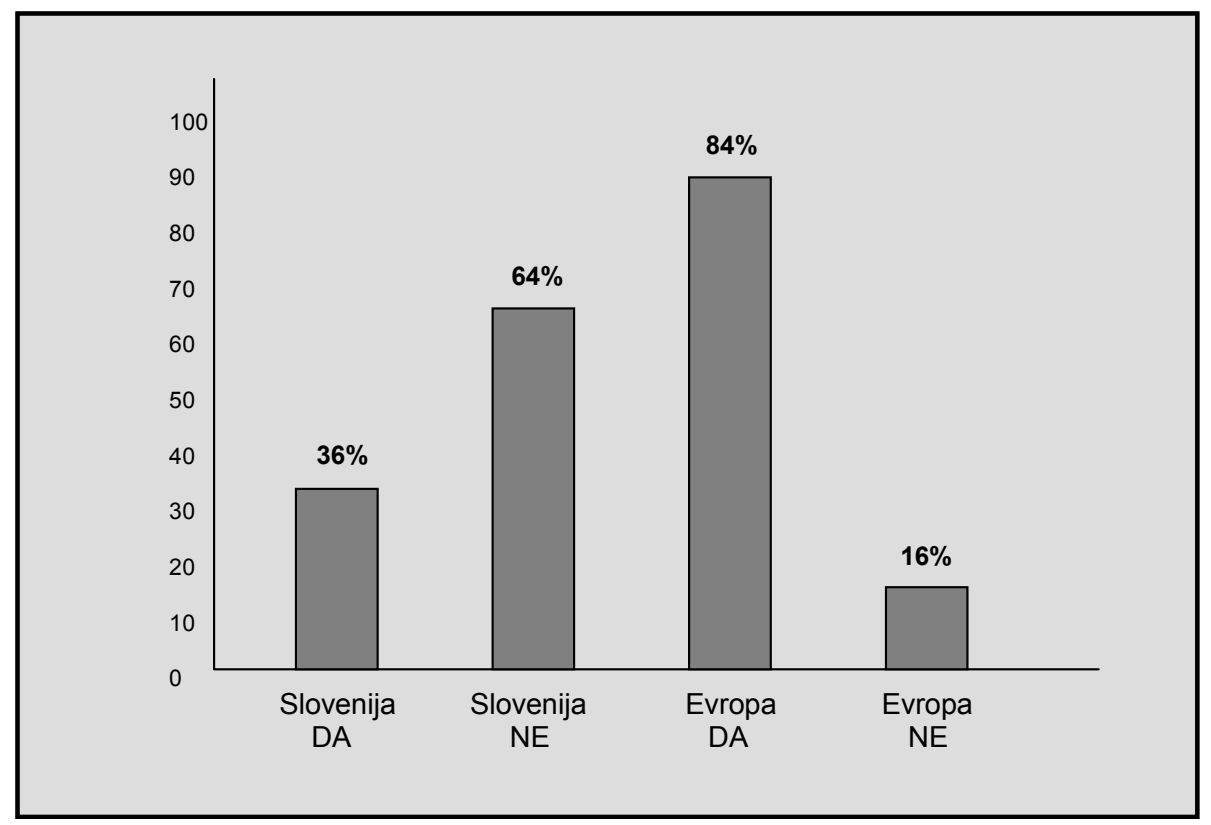

Od oblik internacionalizacije se na fakultetah $v$ Sloveniji izvaja predvsem mobilnost študentov (100\%), sledi: mobilnost akademskega osebja (89\%); mednarodni raziskovalni projekti $(89 \%)$; mednarodne institucionalne pogodbe/mreže (79\%) in vključenost v mednarodna združenja (71\%). Najmanj so prisotne skupne/dvojne diplome (21\%); ponudba izobraževalnih programov fakultete $\vee$ tujini $(18 \%)$; in študij na daljavo (14\%). Kar zadeva mednarodne razsežnosti kurikula je zgolj 56\% fakultet $\vee$ Sloveniji navedlo, da kurikul njihovih študijskih programov zajema tudi mednarodno razsežnost. Ta podatek je še posebej zaskrbljujoč, če se upošteva, da se $v$ zadnjih desetih letih zaradi nenehnih 


\section{Alenka Braček}

\section{Internacionalizacija visokega šolstva}

političnih, družbenih in ekonomskih sprememb kaže potreba po razvoju novih kompetenc, ki omogočajo vsakemu posamezniku učinkovito in uspešno delovanje tako $v$ domačem kot $v$ mednarodnem okolju. Gre za spoznanje, da se je le s socialno kohezijo, medkulturnim dialogom in mednarodnim sodelovanjem mogoče samozavestno soočati z izzivi in tveganji, ki jih $v$ delo in življenje prinašajo globalizacija in evropski integracijski procesi. Te kompetence pa je mogoče doseči le z vključevanjem mednarodne razsežnosti oz. mednarodnih vsebin $\vee$ študijske programe oz. $v$ posamezne študijske predmete. Na podlagi tega podatka lahko razberemo, da se na slovenskih fakultetah, ki so $\mathrm{v}$ raziskavi sodelovale, ta zahteva ne uresničuje.

Slika 2: Relativna razmerja vključenosti posameznih skupin ljudi v procese internacionalizacije

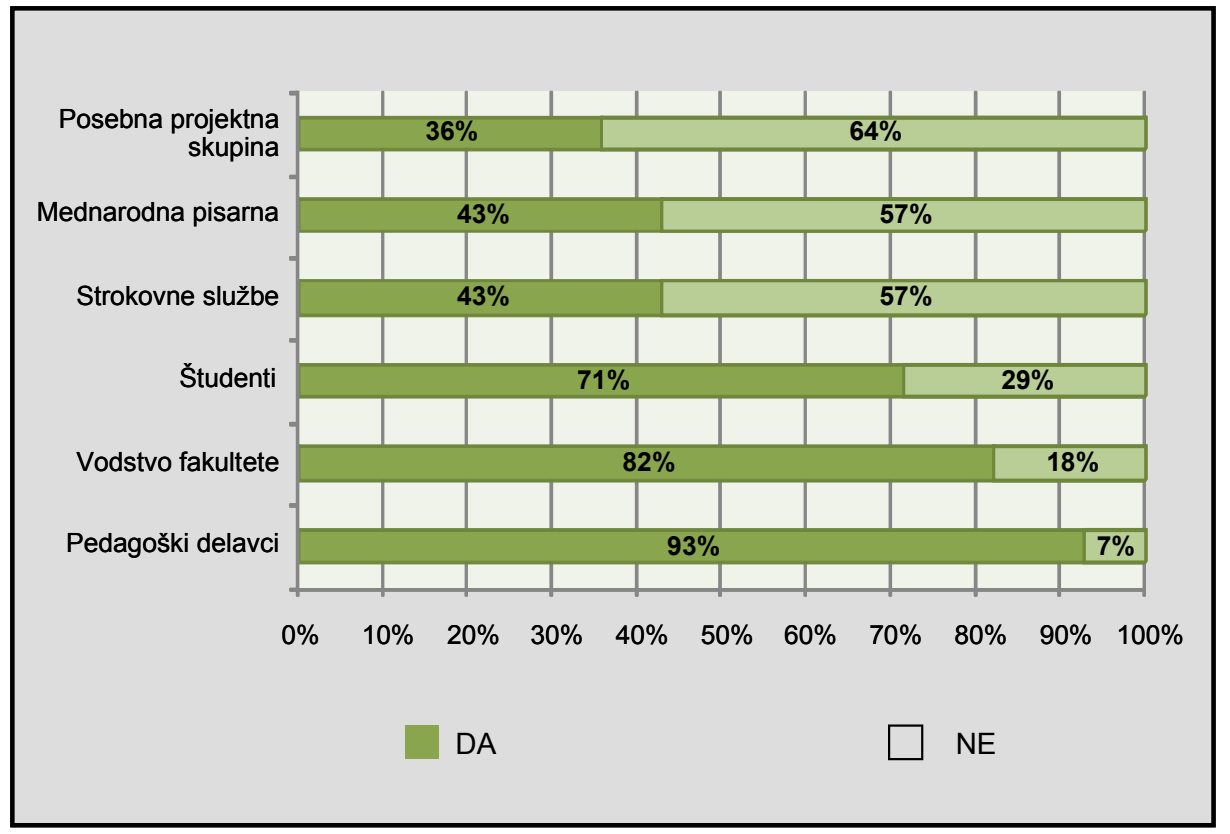

Kar zadeva mobilnosti študentov, ki je pogosto najpomembnejši kazalnik stopnje internacionalizacije visokošolskih institucij, je zaznati, da se je število mobilnosti v Sloveniji v obdobju od leta 2000 do leta 2006 vztrajno povečevalo (glej tabela 2). $\vee$ študijskem letu 2000/01 se je za študij $\vee$ tujini odločilo 230 slovenskih študentov, medtem ko se je $v$ študijskem letu 2005/06 za študij v tujini odločilo že 879 slovenskih študentov. Prav tako je na podlagi podatkov 
Evropske komisije ${ }^{\mathbf{1 6}}$ jasno razviden porast mobilnosti akademskega osebja ter tujih študentov za študij $\vee$ Sloveniji. Vendar pa, če primerjamo podatke ${ }^{17} \mathrm{O}$ mednarodni mobilnosti slovenskih študentov s podatki drugih evropskih držav, ki so vključene $v$ program Erasmus, lahko zaključimo, da je Slovenija na tem področju primerljiva le z Bolgarijo in Slovaško. To lahko pripišemo dejstvu, da so se Slovenija, Bolgarija ter Slovaška vključile v program Erasmus šele leta 1999, večina ostalih evropskih držav pa je začela z mednarodnimi študentskimi izmenjavami že leta 1987. Kljub temu pa je na podlagi podatkov Evropske komisije mogoče opaziti, da Slovenija, ne glede na pozno vključitev $v$ program Erasmus, precej zaostaja za nekaterimi ostalimi evropskimi državami, ki so se prav tako vključile $v$ program šele $v$ poznih devetdesetih letih 20 . stoletja.

Tabela 2: število slovenskih študentov, ki so se odločili za študij v tujini v okviru programa Erasmus, in število tujih študentov, ki se je odločilo za študij v Sloveniji

\begin{tabular}{|l|c|c|c|c|cc|}
\hline Akademsko leto & $2000 / 01$ & $2001 / 02$ & $2002 / 03$ & $2003 / 04$ & $2004 / 05$ & $2005 / 06$ \\
\hline iz Slovenije v tujino & 230 & 364 & 422 & 546 & 742 & 879 \\
\hline iz tujine v Slovenijo & 63 & 112 & 127 & 223 & 396 & 593 \\
\hline
\end{tabular}

Vir: (CMEPIUS, 2006, str. 11)

Obseg mobilnosti akademskega osebja je $v$ absolutnih številkah mnogo skromnejši od števila mobilnosti študentov, vendar je razveseljivo že dejstvo, da je aktivnost prepoznavna in da so jo marsikje že vzeli kot del delovnega procesa. Zanimiv je tudi relativno visok obseg mobilnosti na tehničnih in naravoslovnih področjih, kjer je bila mobilnost študentov manjša. Zelo aktivna so bila področja poslovnih ved, izobraževanja učiteljev, jezikoslovja in družbenih ved (Cmepius, 2006, str. 43).

16 Dokument dosegljiv na European Commission: http://ec.europa.eu/education/programmes/lip/erasmus/stat_en.html 17 Dokument dosegljiv na European Commission: http://ec.europa.eu/education/programmes/llp/erasmus/stat_en.html 
Tabela 3: Število slovenskega akademskega osebja na gostovanjih v tujini v okviru programa Erasmus

\begin{tabular}{|l|c|c|c|c|cc|}
\hline Akademsko leto & $2000 / 01$ & $2001 / 02$ & $2002 / 03$ & $2003 / 04$ & $2004 / 05$ & $2005 / 06$ \\
\hline iz Slovenije v tujino & 60 & 70 & 70 & 73 & 139 & 143 \\
\hline
\end{tabular}

Vir: (CMEPIUS, 2006, str. 43)

$\mathrm{Na}$ podlagi tabele 3 lahko razberemo, da se je zanimanje slovenskega akademskega osebja za gostujoča predavanja $\vee$ tujini $\vee$ okviru programa Erasmus, v primerjavi med študijskima letoma 2000/01 in 2005/06, povečalo več kot za 100\%, kar dokazuje, da ta oblika internacionalizacije visokega šolstva pridobiva vse večji pomen med akademskim osebjem v Sloveniji.

\subsection{Koristi in nevarnosti internacionalizacije visokega šolstva}

Najpogostejše koristi internacionalizacije visokega šolstva, ki jih opažajo fakultete $\vee$ Sloveniji so: izboljšanje kakovosti študijskih programov; povečano mednarodno sodelovanje $z$ drugimi institucijami $v$ tujini ter $s$ tem povečana konkurenčna prednost in izboljšana kakovost študija. Tudi fakultete $\vee$ Evropi vidijo podobne koristi internacionalizacije visokega šolstva, in sicer: povečano medkulturno razumevanje študentov in zaposlenih na fakulteti; izboljšano kakovost študija in v inovacijah kurikula, poučevanja in raziskav.

V zvezi z nevarnostmi internacionalizacije visokega šolstva so fakultete $v$ Sloveniji uvrstile: beg možganov; povečano število tujih diplom ter nizko kakovost ponudnikov le-teh in izgubo kulturne in nacionalne identitete. Ob tem je zanimivo, da fakultete s področja družboslovnih in humanističnih ved opažajo večje nevarnosti internacionalizacije visokega šolstva (64\%) kot fakultete s področja naravoslovnih, inženirskih in tehnoloških ved, medicinskih ter kmetijskih ved (29\%). Na drugi strani pa fakultete v Evropi ugotavljajo, da je komercializacija izobraževalnih programov največja nevarnost internacionalizacije visokega šolstva, sledi ji beg možganov. 


\subsection{Ovire}

Fakultete se pri uvajanju internacionalizacije, tako v Sloveniji kot v Evropi, srečujejo s precejšnjim nizom ovir. Kot najpogostejše ovire pri uvajanju dejavnosti s področja internacionalizacije so fakultete $\vee$ Sloveniji navedle: pomanjkanje finančnih ali materialnih virov ter podpora univerze; pomanjkanje finančne podpore nacionalnih organov; administrativne težave. Fakultete $\vee$ Evropi pa so kot prvo oviro navedle: pomanjkanje zanimanja celotne fakultete; administrativne težave ter pomanjkanje izkušenj ali strokovnega znanja zaposlenih za uvedbo strateškega načrta internacionalizacije.

\subsection{Predlogi za spremembe na področju internacionalizacije visokega šolstva v Sloveniji}

$\mathrm{Na}$ vprašanje, katere spremembe bi lahko prispevale $\mathrm{k}$ izboljšanju stanja na področju internacionalizacije na njihovi fakulteti, so respondenti $\vee$ Sloveniji navedli štiri najpogostejše predloge: vzpostavitev mednarodne pisarne ter zaposlitev strokovnega kadra za mednarodno sodelovanje; ponudba izvajanja predmetov $\vee$ angleškem jeziku; priprava strateškega načrta za internacionalizacijo na ravni fakultete; sprememba mentalitete vodstva in zaposlenih pedagoških delavcev glede večjega sprejemanja in sodelovanja pri različnih aktivnostih internacionalizacije. Na vprašanje, kako bi k izboljšanju stanja na področju internacionalizacije lahko pripomogla matična univerza, so bile navedene naslednje tri rešitve: s finančnimi sredstvi; s svetovalno in strokovno podporo; z izgradnjo študentskih domov za tuje študente in drugih spremljajočih objektov. In ne nazadnje, na vprašanje, kako bi k izboljšanju stanja na področju internacionalizacije $v$ sferi visokega šolstva $v$ Sloveniji lahko pripomogli pristojni nacionalni organi, so sledili naslednji predlogi: s finančno podporo; s krajšimi postopki pri akreditaciji skupnih programov; z večjo promocijo in izdelano strategijo za internacionalizacijo visokega šolstva $v$ Sloveniji. 


\section{Alenka Braček}

\section{Internacionalizacija visokega šolstva}

\section{Priporočila}

$\mathrm{Na}$ podlagi raziskave o stopnji internacionalizacije visokega šolstva $v$ Sloveniji so bila pripravljena priporočila za izboljšanje stanja na področju internacionalizacije ter odpravo poprej naštetih pomanjkljivosti.

Priporočilo fakultetam v Sloveniji:

- priprava strateškega načrta za internacionalizacijo visokega šolstva s spremljanjem in evalvacijo doseženih rezultatov;

- vzpostavitev mednarodne pisarne oz. zaposlitev strokovnega kadra za mednarodno sodelovanje ( $v$ primeru, da te organizacijske enote še nimajo vzpostavljene);

- podpora vodstva ter spodbujanje akademskega in strokovnega osebja k vključevanju v dejavnosti s področja internacionalizacije visokega šolstva;

- uvajanje mednarodnih vsebin $v$ študijske programe oz. v posamezne študijske predmete;

- izvajanje določenih predmetov $v$ angleškem jeziku.

Priporočilo univerzam $\vee$ Sloveniji:

- navodilo vsem članicam, da podpirajo dejavnosti s področja internacionalizacije visokega šolstva;

- navodilo vsem članicam, da pripravijo strateški načrt za internacionalizacijo visokega šolstva s spremljanjem in evalvacijo doseženih rezultatov;

- navodilo vsem članicam, da vzpostavijo mednarodne pisarne oz. zaposlijo strokovni kader za mednarodno sodelovanje (v primeru, da te organizacijske enote še nimajo vzpostavljene);

- dodatna finančna podpora za uvajanje različnih oblik internacionalizacije visokega šolstva ter za vzpostavitev organizacijskih enot za področje mednarodnega sodelovanja;

- navodilo vsem članicam, da študijski programi oz. posamezni študijski predmeti vključujejo tudi mednarodne vsebine;

- navodilo vsem članicam, da začnejo z izvajanjem izbirnih predmetov $v$ angleškem jeziku;

- izboljšanje strokovnega znanja zaposlenih $\vee$ mednarodnih službah matičnih univerz; 


\section{Alenka Braček \\ Internacionalizacija visokega šolstva}

- svetovalna in strokovna podpora tudi pri drugih oblikah s področja internacionalizacije visokega šolstva (in ne samo na področju mobilnosti);

- organizacija posvetov, konferenc, okroglih miz s področja internacionalizacije visokega šolstva;

- izvedba analiz, raziskav ter poročil s področja internacionalizacije visokega šolstva.

Priporočilo Ministrstvu za visoko šolstvo, znanost in tehnologijo RS:

- večja promocija in dodelana strategija za internacionalizacijo visokega šolstva v Sloveniji;

- dodatna finančna podpora za uvajanje različnih oblik internacionalizacije visokega šolstva ter za vzpostavitev organizacijskih enot za področje mednarodnega sodelovanja;

- izboljšana svetovalna in strokovna podpora (MVZT);

- organizacija posvetov, konferenc, okroglih miz na temo internacionalizacije visokega šolstva;

- izvedba analiz, raziskav ter poročil s področja internacionalizacije visokega šolstva;

- krajši postopki pri akreditaciji skupnih programov;

- izgradnja študentskih domov za tuje študente in drugih spremljajočih objektov.

\section{Zaključek}

Področje visokega šolstva in področje, v katerem visoko šolstvo deluje, se $\checkmark$ zadnjem obdobju izrazito spreminjata zaradi številnih razlogov. Ključni dejavniki za te spremembe so: razvoj informacijskih in telekomunikacijskih tehnologij, povečana mobilnost delovne sile, večji poudarek na tržni ekonomiji in liberalizaciji trga, osredotočenost na »na znanju temelječi družbi«, v povečanih privatnih investicijah $\vee$ izobraževanje, na drugi strani pa zmanjšanje javne finančne podpore za izobraževanje ter pomembnost vseživljenjskega učenja. Tako postaja mednarodna razsežnost visokega šolstva čedalje bolj pomembna.

Na podlagi rezultatov kvantitativne raziskave, ki se navezujejo na stopnjo internacionalizacije visokega šolstva $\vee$ Sloveniji ter v Evropi, je bilo ugotovljeno, 


\section{Alenka Braček \\ Internacionalizacija visokega šolstva}

da so podatki glede načinov izvajanja, koristnosti in tveganj internacionalizacije visokega šolstva $\vee$ Slovenji primerljivi s podatki fakultet $\vee$ Evropi. Sklepamo lahko, da tako visokošolske institucije $\vee$ Sloveniji kot $\vee$ Evropi izražajo visoko podporo dejavnostim internacionalizacije visokega šolstva, prav tako opažajo tudi njene izjemne koristi in hkrati tudi nekatere nevarnosti, ki jih internacionalizacija prinaša.

Žal pa je raziskava pokazala, da fakultete $\vee$ Sloveniji, ki so sodelovale $\vee$ raziskavi, na nekaterih področjih precej zaostajajo za fakultetami v Evropi. In sicer, ugotovljeno je bilo, da velika večina fakultet $\vee$ Sloveniji sploh nima izdelanega strateškega načrta oz. programa dela za področje internacionalizacije visokega šolstva in je izvedba določenih aktivnosti internacionalizacije prilagojena zgolj trenutni situaciji. Glede na znanstveno področje fakultet je bilo ugotovljeno, da imajo izdelan program dela pretežno fakultete s področja družboslovnih in humanističnih ved. Večina fakultet s področja naravoslovnih, inženirskih in tehnoloških ved, medicinskih ter kmetijskih ved aktivnosti s področja internacionalizacije visokega šolstva izvaja nenačrtovano. Za uspešnost in učinkovitost procesov internacionalizacije pa je izredno pomemben celovit pristop, kar pomeni, da gre za cikle aktivnosti, ki tečejo vse od postavljanja ciljev (analize potreb po internacionalizaciji), prek določanja oblik in vsebin internacionalizacije, izvajanja internacionalizacije in na koncu do samih rezultatov oziroma vrednotenja in spremljanja uspešnosti internacionalizacije.

Druga pomembna pomanjkljivost, ki se je pokazala pri raziskavi, je, da večina fakultet $\vee$ Sloveniji, ki so $\vee$ raziskavi sodelovale, nima vzpostavljene organizacijske enote (mednarodne pisarne oz. sistemiziranega delovnega mesta za področje mednarodnega sodelovanja), ki bi skrbela za izvedbo aktivnosti s področja internacionalizacije visokega šolstva. Za izvedbo so, predvsem zaradi finančnih razlogov, zadolženi mladi asistenti oz. drugi strokovni delavci, ki pa se poleg rednih pedagoških obveznosti oz. drugih delovnih obveznosti tej dejavnosti ne morejo posvetiti $\vee$ tolikšni meri, kot bi se ji lahko delavci oz. organizacijska enota, ki bi se ukvarjala samo s tem področjem. Ob tem se zastavlja vprašanje glede kakovosti, učinkovitosti in uspešnosti opravljanja te dejavnosti na fakultetah $\vee$ Sloveniji. Nazadnje se lahko na podlagi raziskave o stopnji mobilnosti zaključi, da Slovenija po podatkih o mednarodni mobilnosti študentov precej zaostaja za drugimi evropskimi državami in da primanjkuje mednarodne razsežnosti v vsebinah študijskih programov oz. študijskih predmetov. 
Glede na rezultate raziskave o internacionalizaciji visokega šolstva $v$ Sloveniji bi se morali vsi akterji visokega šolstva $v$ Sloveniji več posvečati internacionalizaciji visokega šolstva ter strateško vodenem uvajanju tega procesa. Obenem bi morali začeti tudi z intenzivno obravnavo vplivov globalizacije, integracijskih procesov, liberalizacije mednarodne trgovine in trgov, ki so $v$ zadnjih treh desetletjih dramatično zaznamovali področje visokega šolstva. Sicer bodo visokošolske institucije $v$ Sloveniji postale izolirane in nekonkurenčne $\vee$ primerjavi s tujimi in privatnimi ponudniki visokošolskih storitev, ki imajo to dejavnost zaradi svoje fleksibilnosti in tržne dejavnosti zelo dobro razvito, kar pa je za študente tudi bolj privlačno in koristno glede na mednarodni trg delovne sile.

Alenka Braček je leta 2003 diplomirala na Fakulteti za socialno delo z nalogo s področja delovno - pravne zakonodaje in pravic delavcev ter leta 2004 na isti fakulteti zaključila specialistični študij z nalogo s področja stigmatizacije in zaposlovanja oseb s težavo $v$ duševnem zdravju. V letu 2004 se je zaposlila na Fakulteti za upravo, kjer je odgovorna za področje mednarodnega sodelovanja fakultete ter uvajanje različnih oblik internacionalizacije na institucionalnem nivoju. V letu 2007 je magistrirala na Fakulteti za družbene vede s področja internacionalizacije visokega šolstva, trenutno pa je doktorska študentka na Fakulteti za družbene vede. 


\section{Alenka Braček \\ Internacionalizacija visokega šolstva}

\section{Literatura}

- $\quad$ Berlinski komunike, (2003).

http://www.dfes.gov.uk/bologna/uploads/documents/Berlin_Communique1.pdf. 18.10.2006

- Bolonjska deklaracija, (1999).

http://www.dfes.gov.uk/bologna/uploads/documents/BOLOGNA_DECLARATION1. pdf. 16.10.2006

- Center za mobilnost in evropske programe izobraževanja in usposabljanja (CMEPIUS), (2006): Vseživljenjsko učenje. Ljubljana.

- Commission of the European Communities, (2002): Detailed work programme on the follow-up of the objectives of educational and training systems in Europe. http://eric.ed.gov/ERICWebPortal/contentdelivery/servlet/ERICServlet?accno=ED47 9339. 15.10.2006

- European Commission, (2004): Education \& training 2010: The Success of the Lisbon Strategy Hinges on Urgent Reforms. Joint interim report of the Council and the Commission, Brussels, European Commission. http://ec.europa.eu/education/policies/2010/doc/jir_council_final.pdf. 5.12.2006.

- Gibbs, P. (2001): Higher education as a market: a problem or solution? London. Studies in Higher Education Studies in Higher Education, let. 26, št. 1, str. 85-95.

- Graška deklaracija, (2003). http://www.eua.be/eua/jsp/en/upload/COM_PUB_Graz_publication_final.106932610 5539.pdf. 15.10.2006.

- International Association of Universities (IAU), (2003): Internationalization of Higher Education: Practices and Priorities.

http://www.unesco.org/iau/internationalization/pdf/Internationalisation-en.pdf. 13.10.2006

- Javna agencija za raziskovalno dejavnost RS (ARRS), (2006): Področja znanosti in tehnike po Frascatskem priročniku. http://www.arrs.gov.si/sl/gradivo/sifranti/inc/siffrascati.pdf. 5.2.2007.

- Knight, J. (2004): Internationalization Remodelled: Definitions, Rationales and Approaches. Journal for Studies in International Education, let. 8, št. 1, str. 5-31.

- $\quad$ Knight, J. (2005): Internationalization- the New World of Crossborder Education Developments, Complexities and Challenges. http://www.itpnz.ac.nz/conferences/2005_Nov_ITP_Conf/Jane_Knight_International isation.pdf. 20.7.2006.

- Knight, J. (2006): 2005 IAU Global Survey Report: Internationalization of Higher Education: New Directions, New Challenges. Pariz. International Association of Universities (IAU). 


\section{Alenka Braček
Internacionalizacija visokega šolstva}

- $\quad$ Larsen, K., Martin, P. J., Morris, R. (2002): Trade in Educational Services: Trends and Emerging Issues. Organisation for Economic Co-operation. Pariz. http://www.oecd.org/dataoecd/54/44/2538356.pdf. 24.12.2006.

- $\quad$ Lizbonska strategija, (2000).

http://consilium.europa.eu/ueDocs/cms_Data/docs/pressData/en/ec/00100r1.en0.htm. 18.10.2006.

- Lorber, L. (2004): Med tradicijo visokega šolstva in prenovo: $V$ razmislek ob oblikovanju razvojne vizije Univerze na Primorskem.

http://www.upr.si/sl//zobrazevanje/Prenova/prenova/strateska_konferenca/01_Luck a_Lorber.doc. 15.1.2007.

- Magna Charta Universitatum, (1988). http://www.bologna-bergen2005.no/Docs/00Main_doc/880918_Magna_Charta_Universitatum.pdf. 16.10.2006.

- Ministrstvo za šolstvo in šport RS (1995): Bela knjiga o vzgoji in izobraževanju v Republiki Sloveniji. Ljubljana.

- Praški komunike, (2001).

http://www.dfes.gov.uk/bologna/uploads/documents/PRAGUE_COMMUNIQUE2.p df. 20.10.2006.

- Sorbonska deklaracija, (1998).

http://www.dfes.gov.uk/bologna/uploads/documents/SORBONNE_DECLARATION 1.pdf. 16.10.2006.

- $\quad$ Stare, M. (2002): Celovit pristop k razumevanju in zajemanju mednarodne menjave storitev. Delovni zvezek UMAR, let. XI, št. 6. Ljubljana: Urad RS za makroekonomske analize in razvoj.

- Svetličič, M. (1996): Svetovno podjetje: Izzivi mednarodne proizvodnje. Ljubljana: Znanstveno in publicistično središče.

- Študentska deklaracija iz Göteborga, (2001). http://www.seeeducoop.net/education_in/pdf/student-goteborg-declaration-oth-sln-t02.htm. 16.10.2006.

- Tsuruta, Y. (2005): Internationalisation of Higher Education: An Analysis of Recent Contexts and Some Components. http://www.gcn-osaka.jp/project/finalreport/1/13e.pdf. 20.11.2006.

- UNESCO (2004): Final report of the Meeting of Higher Education Partners (World Conference on Higher Education + 5), Paris, 23-25 June 2003.

http://unesdoc.unesco.org/images/0013/001352/135213e.pdf. 14.12.2006.

- Zgaga, P. (2004): Bolonjski proces. Univerza v Ljubljani, Pedagoška fakulteta, Center za študij edukacijskih strategij.

- Zgaga, P. (2005): Some Theses on Higher Education vs. State: Transition and PostTransition Countries. http://www.nsinitiative.ns.ac.yu/docs/P3_Pavel_Zgaga.pdf. 21.12.2006. 


\author{
Alenka Braček \\ Internacionalizacija visokega šolstva
}

SUMMARY

\title{
INTERNATIONALIZATION OF HIGHER EDUCATION
}

The world of higher education and the world in which higher education plays a significant role are changing, for many reasons. Key drivers include the development of advanced communication and technological services, increased international labor mobility, greater emphasis on the market economy and trade liberalization, the focus on the knowledge society, increased private investment and decreased public support for education, and the growing importance of lifelong learning. The international dimension of higher education is therefore becoming increasingly important and, at the same time, more complex.

While it is encouraging to see the increased use and attention being given to internationalization, there is a great deal of confusion about exactly what it means. For some it means international activities, such as academic mobility for students and teachers; international linkages, partnerships, and projects; and new international academic programs and research initiatives. For others it means the delivery of education to other countries through new types of arrangements, such as branch campuses or franchises, and the use of a variety of face to face and distance techniques. To many it means the inclusion of an international, intercultural, or global dimension in the curriculum and the teaching/ learning process. Still others see international development projects and the increasing emphasis on trade in higher education as internationalization. There is frequent confusion and some tension over the fact that the term internationalization is used to describe three very different types of crossborder activities: international exchanges and partnership, cross border commercial trade ventures, and international development projects. There is also continuing debate and exploration of the relationship between internationalization and globalization. However, the definition of internationalization of higher education that is popular and widely used is: Internationalization of higher education at the national, sectoral, and institutional level is the process of integrating an international, intercultural or global dimension into the purpose, functions or delivery of postsecondary education (Knight, 2004, p. 6). This definition understands internationalization as an ongoing and continuing process of making something international, not just a set of activities. 
It is impossible to look at new conceptual frameworks for internationalization without considering the realities of the environment in which higher education is operating. There are many changes and new challenges in terms of how the environment is affecting internationalization and how the growing international dimension of higher education is an agent of change itself. Globalization is probably the most pervasive and powerful feature of the changing environment of higher education. The concepts of worldwide movement and flow are crucial for the interpretation of globalization in this paper. A number of factors are closely related to this flow and seen as integral elements of globalization. These include the knowledge society, information and communication technologies, the market economy, trade liberalization, and changes in governance structures. It can be debated whether these are catalysts for or consequences of globalization; in this paper they are presented as elements or factors of globalization that have an enormous impact on the education sector. The paper describes each of these five elements of globalization and notes some of the key implications for higher education in general and the international dimension in particular. It illustrates some of the major environmental changes shaping the responses and actions of internationalization to globalization. These changes affect all aspects of internationalization, including the curriculum and teaching process, student and academic mobility, the cross-border delivery of education programs, international development projects, study of foreign languages, commercial trade, and staff development.

Powerful features of the changing environment of higher education in Europe are establishment of European higher education area and Lisbon strategy. Currently, European countries have been promoting the Bologna Process for the establishment of a European higher education area by 2010, and for facilitating the bachelor-master (or bachelor-master-doctor) system (underlining the distinction between undergraduate and graduate programmes), the recognition of credits and degrees (using the ECTS, the Diploma Supplement and others) and cooperation in the areas of quality assurance and information provision to increase mobility, transferability and transparency. The European Union has also been implementing the Copenhagen Process to promote exchange and transferability in vocational education and training, and the Lisbon Strategy to make the European Union the most dynamic and competitive knowledge-based economy in the world by 2010 . The strategy aims at the enhancement of the competitiveness of Europe (in productivity, employment, science and technology) 
Alenka Braček

Internacionalizacija visokega šolstva

and respect for the environment, as well as greater social cohesion and the realization of lifelong learning for all. The framework of a European higher education area is expected to enable closer cooperation between higher education institutions, facilitate student and staff mobility and increase both the competitiveness of Europeans in the world labor market and the attractiveness of European higher education in the world. The basic aims of the Bologna Process and Lisbon Strategy can thus be summarized in three key words: mobility, employability and competitiveness. So far, ten aims have been established that will lead to the creation of European higher education area. To meet the requirements of European higher education area, higher education institutions will have to fulfill all of them. In all of these aims there is a strong emphasis on internationalization of higher education.

Last but not least powerful feature of the changing environment of higher education is diversification of funding sources. Funding and support for higher education represent key changes and challenges for internationalization. Several trends are converging and have a major impact. The growing demand for higher education is making it difficult for governments to meet demand. At the global level, private investment in education is rising more rapidly than public funding. This has resulted in several important trends, including the diversification, privatization, and commercialization of higher education and its funding sources. Therefore it is more and more common and necessary for institutions, both public and private, to search for alternative sources of income. These sources include funding from social foundations and the private corporate sector, income from the commercialization of research findings, and income from feebased education for domestic and international students and from other means of cross-border education delivery. Income generation from the importing and exporting of education programs is expected to increase at a significant rate in the next decade. Trade in higher education services is expected to be highly competitive, and new commercial providers are likely to have an impact on public and private nonprofit higher education institutions that are active in this area.

The internationalization of higher education institutions is, with no doubt, a reaction to the somewhat recent trend of socio-economic and cultural processes that seem, more and more, to integrate diverse local and national entities into a single global whole. This trend, invariably, implies substantial changes also for higher education institutions in 
Slovenia. In an era of increased global competition, higher education institutions cannot afford to stay in the old bureaucratic model. Threats from the corporate world and state agencies concerning the production of knowledge and innovation in a world characterized by an increasingly educated society, fierce market competition, a growing separation of teaching and research, privatization's, lifelong learning, institutional mergers, virtual classrooms and global communications, have had a tremendous impact on the way universities and faculties work.

This paper presents a picture of recent worldwide developments in higher education. It first defines the meaning and definition of the term of internationalization of higher education and introduces four most powerful features of the changing environment of higher education in Europe: globalization, Bologna Process, Lisbon Strategy and diversification of funding sources. All mentioned features are also described as rationales for internationalization of higher education. Finally, the last chapter presents research about the level of internationalization in Slovenian public faculties. The survey has been designed to track some of the major developments and issues in the field of internationalization of higher education. The objectives of the survey were the following: identify key issues, trends and areas of growth; provide information on the practices and priorities of internationalization at the institutional level; ensure that the voice of higher education institutions is heard in the ongoing discussion of the purpose, rationales, risks, benefits, issues and trends of the international dimension of higher education. The paper also compares some internationalization issues in higher education in Slovenia and Europe and ends with recommendations for improvement the current situation in the field of internationalization of higher education in Slovenia. 